\title{
Evolution of milk somatic cell count of cows grazing an alpine pasture according to the infection of udder by pathogens
}

\author{
Alexandre LAMARCHE ${ }^{\mathrm{a}}$, Bruno MARTin ${ }^{\mathrm{b} *}$, Agnès HAUWuY ${ }^{\mathrm{a}}$, \\ Jean-Baptiste Coulon $^{\mathrm{b}}$, Bernard POUTREL ${ }^{\mathrm{c}}$ \\ a SUACI-GIS Alpes-du-Nord, 11 rue Métropole, 73000 Chambéry, France \\ b Unité de Recherches sur les Herbivores, INRA, Theix, 63122 Saint-Genès-Champanelle, France \\ ${ }^{c}$ Laboratoire de Pathologie Infectieuse et d'Immunologie, INRA, 37380 Nouzilly, France
}

(Received 13 January 1999; accepted 23 November 1999)

\begin{abstract}
The infection of udder by a pathogen and milk somatic cell count (SCC) of 220 quarters from 55 Abondance and Tarentaise cows coming from three Northern Alps herds were analysed three times: in June when cows use a valley pasture before turning to highland pasture and in July and September, respectively at the beginning and the end of highland pasture grazing period. During the three periods, $31 \%$ of the experimental quarters were free or infection, $61 \%$ were infected by a minor pathogen and $8 \%$ were infected by a major pathogen. In quarters infected by a major pathogen, SCC was constantly high (> $1600000 \mathrm{cells} / \mathrm{ml}$ in the three periods). SCC of uninfected quarters remained below 60000 cells $/ \mathrm{ml}$ in the three periods whereas SCC of quarters infected by a minor pathogen averaged $89000 \mathrm{cells} / \mathrm{ml}$ in June and $512000 \mathrm{cells} / \mathrm{ml}$ in September. For the latter, SCC was all the higher as the infection was older. Results are discussed according to the highland grazing conditions that may have had an impact on SCC.
\end{abstract}

milk / somatic cell count / udder infection / highland pasture

Résumé - Évolution au cours de l'alpage de la concentration en cellules somatiques du lait de vache en relation avec l'état infectieux des mamelles. Le statut infectieux et la concentration en cellules somatiques (CCS) du lait de 220 quartiers issus de 55 vaches de race Abondance et Tarentaise ont été analysés à 3 reprises - avant la montée en alpage lorsque les animaux utilisent des pâturages de vallée (juin), en début de saison d'alpage (juillet) et en fin de saison d'alpage (septembre) - dans 3 troupeaux des Alpes du Nord. Les animaux ont été choisis sur la base de leur concentration en cellules somatiques hivernale (toujours inférieure à 100000 et 500000 cellules/ml pour respectivement $75 \%$ et $25 \%$ des animaux). La CCS des laits des quartiers a été mise en relation avec le statut infectieux des quartiers, la conformation des mamelles, le stade de lactation des animaux, le troupeau

* Correspondence and reprints

Tel.: +33 (0)4 736243 58; fax: +33 (0)4 736241 18; e-mail: bmartin@clermont.inra.fr 
et la période. Au cours des 3 périodes, $31 \%$ des quartiers analysés ont été trouvés non infectés, $61 \%$ étaient infectés par un pathogène mineur et $8 \%$ étaient infectés par un pathogène majeur. La CCS des laits de quartiers a varié en premier lieu en fonction de leur état infectieux : celle des quartiers non infectés a été de 46000 cellules/ml alors que celle des quartiers infectés par un pathogène mineur et majeur a été respectivement de 152000 et 1622000 cellules/ml. En comparaison, l'influence des autres facteurs testés a été moindre bien que significative. Une forte interaction entre le statut infectieux et la période a également été observée. La CCS des quartiers infectés par un pathogène majeur a été constamment élevée (supérieure à 1600000 cellules/ml aux 3 périodes). La CCS des quartiers non infectés est restée inférieure à 60000 cellules/ml aux 3 périodes alors que celle des quartiers infectés par un pathogène mineur était en moyenne de 89000 avant la montée en alpage et de 512000 cellules/ml en fin d'alpage. L'augmentation a été d'autant plus importante que l'infection était plus ancienne. La CCS des laits de quartiers infectés par un pathogène mineur a diminué après la descente d'alpage (-128 000 cellules/ml). Les résultats sont discutés en fonction des différentes conditions de l'alpage pouvant expliquer son effet sur la CCS. Ces résultats montrent que dans les régions où l'utilisation d'alpages est fréquente, il est important de prévenir les infections, y compris celles dues à des pathogènes mineurs qui, dans ces conditions, peuvent contribuer de manière plus importante à la CCS des laits de tank et donc pénaliser l'éleveur.

\section{lait / concentration en cellules somatiques / état infectieux / alpage}

\section{INTRODUCTION}

Somatic cell count (SCC) is a significant factor of milk quality valuation. It is a well known indicator of udder inflammation secondary to infection $[17,23]$ whose basic risks are linked to the animals [16] or husbandry conditions (milking, housing) [21, 23]. Udder infections are responsible for a decrease in milk yield $[6,14]$ and alteration of the milk characteristics [2, 12] which may induce sanitary or technological consequences $[4,23]$. In the absence of mastitis, the lactation stage or parity [2, 20, 22, 24], the age $[13,20]$ or the breed [8] have an impact on milk SCC. It has recently been demonstrated, under experimental conditions, that prolonged and forced walking by cows could induce an increase in SCC [7] all the more marked as the udder was previously infected [9]. Milk SCC in Northern Alps herds sometimes remains high in certain situations, in summer in particular and especially in breeders who use alpine pastures [1], without any clear explanation for that finding.

The aim of this study was to analyse the respective effects of udder infection by pathogens and husbandry conditions of herds grazing an alpine pasture on SCC evolution during the summer period.

\section{MATERIALS AND METHODS}

\subsection{Animal and herd characteristics (Tab. I)}

The study was conducted in 3 herds using alpine pastures in the area where Beaufort cheese is produced (Savoie, France). Herds were composed of cows coming from a single farm on one case and from a grouping of cows from several farms on the other two. Stocking rate, steepness, displacement of the milking machine and milking methods were different from one herd to the other (Tab. I). In particular, teat cleaning was limited to a hand wiping in herd 1 whereas the udders were scrubbed with a single-use piece of dry paper in herd 2 or washed in water and wiped with a single-use paper in herd 3. At the end of milking, grease was occasionally (herds 1 and 3 ) or systematically (herd 2) used. In addition, a disinfectant was systematically sprayed on the teats of herd 3 cows. 
Table I. Main characteristics of farms and herds.

\begin{tabular}{lccc}
\hline & Herd 1 & Herd 2 & Herd 3 \\
\hline Number of cow during winter & 43 & 35 & 113 \\
Number of cows in alpine pasture & 43 & 120 & 200 \\
Winter (1997) SCC (cells/ml) $*$ & 40000 & 80000 & 150000 \\
SCC in alpine pasture season (1996) (cells/ml) * & 350000 & 500000 & 600000 \\
Minimum elevation of alpine pasture (m) & 1300 & 1200 & 1300 \\
Maximum elevation of alpine pasture (m) & 1900 & 2000 & 2300 \\
Period 1 & & & \\
Milk yield (kg/cow/day) & 16.2 & 16.9 & 19.8 \\
Fat (g/kg) & 39.0 & 37.3 & 35.7 \\
Protein (g/kg) & 29.4 & 32.5 & 33.4 \\
Lactation stage (days) & 107 & 143 & 142 \\
Non infected quarters $(\%)$ & 53 & 21 & 35 \\
Displacements of cows** & ++ & + & + \\
Steepness of the grazing areas** & 0 & ++ & ++ \\
Period 2 & & & \\
Milk yield (kg/cow/day) & 19.2 & 15.0 & 17.1 \\
Fat (g/kg) & 44.4 & 38.6 & 31.3 \\
Protein (g/kg) & 30.7 & 32.1 & 32.5 \\
Non infected quarters (\%) & 33 & 36 & 25 \\
Displacements of cows** & + & + & + \\
Steepness of the grazing areas** & + & ++ & ++ \\
Period 3 & & & \\
Milk yield (kg/cow/day) & 9.0 & 10.0 & 14.6 \\
Fat (g/kg) & 53.4 & 36.5 & 33.4 \\
Protein (g/kg) & 31.2 & 34.9 & 34.4 \\
Non infected quarters $(\%)$ & 28 & 24 & 25 \\
Displacements of cows** & ++ & + & +++ \\
Steepness of the grazing areas** & ++ & +++ & +++ \\
Decrease of milk yield between & 45 & 41 & 26 \\
periods 1 et 3 (\%) & & & \\
\hline
\end{tabular}

* Herd geometric mean (data from Contrôle Laitier Savoie (73)).

** 0; nil. +; small. ++; medium. +++; important.

Fifteen to 20 Abondance and Tarentaise cows were selected from each herd according to their lactation stage (under 5 months at the beginning of the trial) and to their SCC in January and April preceding the trial (data provided by the Contrôle Laitier de la Savoie, 1997). To include a high number of non-infected quarters before going up to alpine pasture, $75 \%$ of the animals picked in each herd had a SCC constantly below 100000 from January to April. Other cows had SCC always below 500000 cells/ml.

\subsection{Sampling and analyses}

In total, 220 quarters from 55 cows were followed-up. Milk samples were taken during three periods: before turning to alpine pasture when cows were grazing on valley pasture and when milking was performed outside with the same milking machine and persons as in alpine pasture (26 May-7 June), at the beginning of alpine pasture season (7-16 July) and at the end of the alpine pasture season (29 August-4 September). In 
the course of each period two milk samples were collected from each experimental quarter: one for SCC and the other one for bacteriological characterisation. During periods 1 and 2, these two samplings were performed with one-day interval and during the third period, the specimen for bacteriological analyse was sampled 6 days before and 6 and 9 days after that for SCC in herds 1, 2 and 3, respectively. Of 18 cows of herds 2 and 3 (46 quarters), an additional sampling was performed after returning from alpine pasture (late October), when cows were grazing in the valley. Samples for bacteriology and SCC were collected from the same milking.

Samples were collected manually during the evening milking after the first ejection. Samples for SCC $(30 \mathrm{ml})$ were added bronopol and stored at $+4{ }^{\circ} \mathrm{C}$. Somatic cells were counted by epifluorescence microscopy (Fossomatic 360, Foss Electric, Hillerod, Danemark). Quarter milks for bacteriological analyses were sampled in an aseptic manner. The samples were immediately chilled to $+4{ }^{\circ} \mathrm{C}$ and frozen $\left(-18{ }^{\circ} \mathrm{C}\right)$ within
3 hours following collection. In the laboratory, $0.025 \mathrm{ml}$ of each sample of quarter milk were spread on sheep blood gelose with esculin. After aerobic incubation for 24 to $48 \mathrm{~h}$ at $37^{\circ} \mathrm{C}$, the germs were identified according to international NMC guidelines [15].

Pathogens identified were divided in two groups [17] (Tab. II): major pathogens (Staphylococcus aureus, Streptococcus dysgalactiae, Streptococcus agalactiae, Streptococcus uberis and other Streptococcus sp.) and minor pathogens (negative coagulase Staphylococcus: SC- and Corynebacterium bovis: CB). Quarters were considered as not infected when microbiological test was negative. Quarters were considered as infected by a minor pathogen when at least one was present in the absence of a major pathogen. Lastly, quarters were considered infected by a major pathogen when at least one was present with or without a minor pathogen.

Individual milk yield, fat and protein content and the lactation stage results were given by the Contrôle Laitier de la Savoie.

Table II. Inventory of the udder pathogens.

\begin{tabular}{lcc}
\hline Infectious status & Number of samples & $\%$ \\
\hline No pathogen & 201 & 31 \\
Minor pathogens & 387 & 61 \\
$\quad$ Negative coagulase Staphylococcus & 46 & \\
Corynebacterium bovis & 269 & \\
2 minors pathogens & 72 & 8 \\
Major pathogens & 52 & \\
$\quad$ Staphylococcus aureus & 16 & \\
Streptococcus dysgalactiae & 2 & \\
Streptococcus agalactiae & 23 & \\
Streptococcus uberis $*$ & & \\
Streptococcus species & 1 & \\
2 majors pathogens & 4 & \\
1 major + 1 minor pathogen & 6 & \\
Subtotal & 640 & \\
Non usable samples & 20 & \\
Total & 660 & \\
\hline
\end{tabular}

\footnotetext{
* Always with other minor pathogen.
} 


\subsection{Observations on the cows and on the pastures}

The cows' udder conformation was assessed once in the course of the trial, from the height of the tip of rear teats in relation to the hock: above, at the same height or below the horizontal plane passing by the top of the hock. During the third period, when the herds were using areas near the top of the alpine pastures, cows displacement was assessed by plotting them individually on a 1/3000th chart every 30 minutes between the morning milking and sunset. During the first two periods, the herds were placed on small plots and these observations were not made. Because of the proximity of the milking machine and the restricted area of the night plot, the mean daily displacement of the cows was below $3 \mathrm{~km}$.

The quarters that were treated for mastitis, the treatment products used and the administration methods were noted during each period.

\subsection{Statistical analyses}

The quarters that underwent medical treatment between two samplings of the same period $(n=12)$ or for which the type of pathogen had changed from one period to another without the quarter being treated $(n=21)$ were excluded from data analysis. Statistical analyses for SCC were performed based on data expressed as decimal logarithms. The results presented in the tables, the text and figures have been converted into geometric means.

In a first step, all useable SCC were processed by analysis of variance (GLM procedure [19]) by introducing in the model the effects of the infectious status, the period, the herd, the lactation stage of the cows during the first period ( 3 classes: $<100$ days, between 100 and 150 days and > 150 days), the height of the teat bottom in relation to the hock and the interactions between infection and period, herd and period and lactation stage and period. The latter interaction was not significant and was not included in the final model.

In a second step, SCC evolutions were explored according to the infectious status of quarters in the three periods. Three hundred and ninety six observations were retained, distributed among five groups: quarters not infected in any period, not infected in the first two periods then infected by a minor pathogen, not infected in the first period then infected by a minor pathogen in the last two periods, infected by a minor pathogen in the three periods, and lastly infected by a major pathogen in the three periods. The statistical model used was identical to that previously described.

Lastly, SCC in quarters infected by minor pathogens in periods 3 and 4 was compared by analysis of variance by introducing the period and the quarter in the model.

\section{RESULTS}

On average, individual daily milk yield varied from $17.7 \mathrm{~kg}$ during period 1 and $11.3 \mathrm{~kg}$ during period 3 (Tab. I). Clinical mastitis were noted in 38 quarters ( 9 in period 2 and 29 in period 3). These quarters were medically treated. None of those quarters was used in the second statistical analysis. In contrast, for the first analysis, only those quarters that were treated between the sampling of the bacteriological specimen and that for SCC specimen were excluded (4 in period 2 and 8 in period 3 ).

\subsection{Inventory of non infected and infected quarters}

The proportion of quarters not infected during the 3 sampling periods averaged at $31 \%$ (35\% in period 1 and $25 \%$ in period 3 ). Although the proportion of non-infected quarters differed from one herd to the other during period 1 (53, 33 and $28 \%$ in herds 1,2 and 3 , respectively), the proportion of 
non-infected quarters at the end of alpine pasture season was $25 \%$ in all 3 herds alike. Minor pathogens were found in $88 \%$ of infected quarters. Corynebacterium bovis was largely predominant among minor pathogens, by comparison with negative coagulase Staphylococci (Tab. II). Major pathogens were found in $12 \%$ of infected quarters. They were most often found in herd 3 where they represented $26 \%$ of infected quarters. Streptococcus agalactiae and Staphylococcus aureus were the most frequent. Streptococcus agalactiae was only found in herd 3.

\subsection{SCC variation factors (Tab. III)}

The mean SCC of the milk from animals whose lactation stage was under 100 days during the first period was significantly lower $(P<0.001)$ than that of cows whose lactation stage was above 150 days $(129000$ vs. 257000 cells $/ \mathrm{ml})$. The mean SCC was 324000 cells $/ \mathrm{ml}$ in cows where the tip of the teats was below the hock and below 200000 cells $/ \mathrm{ml}$ in those where the teat tip was at the same level or above the hock $(P<0.001)$. The herd also had a significant effect on SCC $(P<0.01)$; it was lower in

Table III. Somatic cell count variation factors.

\begin{tabular}{|c|c|c|c|}
\hline & $\mathrm{nb}$ & $\mathrm{SCC}($ cells $/ \mathrm{ml})$ & significance \\
\hline Quarter infectious status & & & $* * *$ \\
\hline Not infected & 197 & 45709 & $\mathrm{a}$ \\
\hline Corynebacterium bovis & 246 & 151356 & $\mathrm{~b}$ \\
\hline Negative coagulase Staphylococcus & 35 & 194984 & $\mathrm{~b}$ \\
\hline Corynebacterium bovis and negative & & & \\
\hline coagulase Staphylococcus & 68 & 138038 & $\mathrm{~b}$ \\
\hline Major pathogen ${ }^{1}$ & 41 & 1621810 & $\mathrm{c}$ \\
\hline Period & & & $* * *$ \\
\hline 26 May-7 June & 198 & 100000 & a \\
\hline 7-16 July & 195 & 199526 & $\mathrm{~b}$ \\
\hline 29 August-4 September & 194 & 398107 & $\mathrm{c}$ \\
\hline Herds & & & $* *$ \\
\hline 1 & 191 & 194984 & $a b$ \\
\hline 2 & 183 & 257040 & $\mathrm{~b}$ \\
\hline 3 & 213 & 158489 & a \\
\hline Lactation stage in period 1 & & & $* * *$ \\
\hline$<100$ days & 166 & 128825 & $\mathrm{a}$ \\
\hline $100-150$ days & 212 & 234423 & $\mathrm{~b}$ \\
\hline$>150$ days & 209 & 257040 & $\mathrm{~b}$ \\
\hline Height of the tip of the teats & & & *** \\
\hline above the hock & 221 & 181970 & b \\
\hline at the same level of the hock & 181 & 131826 & a \\
\hline below the hock & 185 & 323594 & $\mathrm{c}$ \\
\hline \multirow{2}{*}{\multicolumn{3}{|c|}{$\begin{array}{l}\text { Infectious status * period } \\
\text { herd } * \text { period }\end{array}$}} & $* * *$ \\
\hline & & & ns \\
\hline
\end{tabular}

${ }^{1:}$ Staphylococcus aureus or Streptococcus dysgalactiae or Streptococcus agalactiae or Streptococcus uberis or other Streptococcus sp.

a.b.c: values with different letters are different at 0.05 level of significance.

ns: not significant; $* *: P<0.01 ; * * *: P<0.001$.

Residual Standard Deviation $=0.55(\log ($ cells $/ \mathrm{ml}))$. 
herd 3 (158 000 cells $/ \mathrm{ml})$, higher in herd 2 (257 000 cells $/ \mathrm{ml}$ ) and medium in herd 1 (195000 cells/ml).

The mean SCC of quarters not infected or infected by a minor or major pathogen was 46000,152000 and 1622000 cells/ml, respectively $(P<0.001)$. No significant difference was noted between the SCC of quarters infected by a minor pathogen according to the infectious agent $(\mathrm{CB}, \mathrm{SC}$ - or $\mathrm{CB} / \mathrm{SC}-)(P>0.1)$. The SCC means were higher during the two alpine pasture periods $(P<0.001) ; 100000$ cells $/ \mathrm{ml}$ in period 1, 200000 cells $/ \mathrm{ml}$ in period 2 and 398000 cell $/ \mathrm{ml}$ in period 3 . There was no interaction between infection and herd $(P>0.1)$. In contrast, a strong interaction was noted between infection and the period $(P<0.001)$.

\subsection{SCC evolution according to quarter infectious status}

The mean SCC of quarters not infected in the 3 periods increased significantly $(P<0.01)$ between periods 1 and 3 (Fig. 1) although that increase was not important (+ 36000 cells $/ \mathrm{ml}$ ). The SCC of quarters infected by a major pathogen in the three periods was always above 1600000 cells $/ \mathrm{ml}$; the average decrease noted was not significant. In contrast, the mean SCC of quarters infected by a minor pathogen in the three periods increased much more between periods 1 and 3 (+ 423000 cells $/ \mathrm{ml}, P<0.001)$. That increase was all the more marked as infection occurred earlier (Fig. 1): the mean SCC of quarters that became infected between periods 1 and 2 and remained infected to the end increased by 315000 cells $/ \mathrm{ml}$ $(P<0.001)$ whereas that of quarters that became infected between periods 2 and 3 increased by 122000 cells/ml $(P<0.001)$. The mean SCC in period 3 was higher in herd 2 (Fig. 2) where SCC was higher than in the other 2 herds in period $1(P<0.001)$. Also, between periods 2 and 3 , the mean increase in SCC was higher in herd 3 than in herd 1. After returning from alpine pasture, the mean SCC of quarters infected by a minor pathogen decreased significantly $(P<0.05): 300000$ cells $/ \mathrm{ml}$ in period 3 and 182000 cells/ml in period 4 (Fig. 3).

\section{DISCUSSION}

In our trial, the mean SCC of milk in May-June was clearly lower than noted by Agabriel et al. [1] in the same period in 50 Northern Alps herds. This can be explained by our decision to include in our sample a large proportion of quarters that were not infected before turning to alpine pasture. That proportion was slightly lower than observed by Faye et al. [10] in cows in early lactation in Brittany farms. The number of

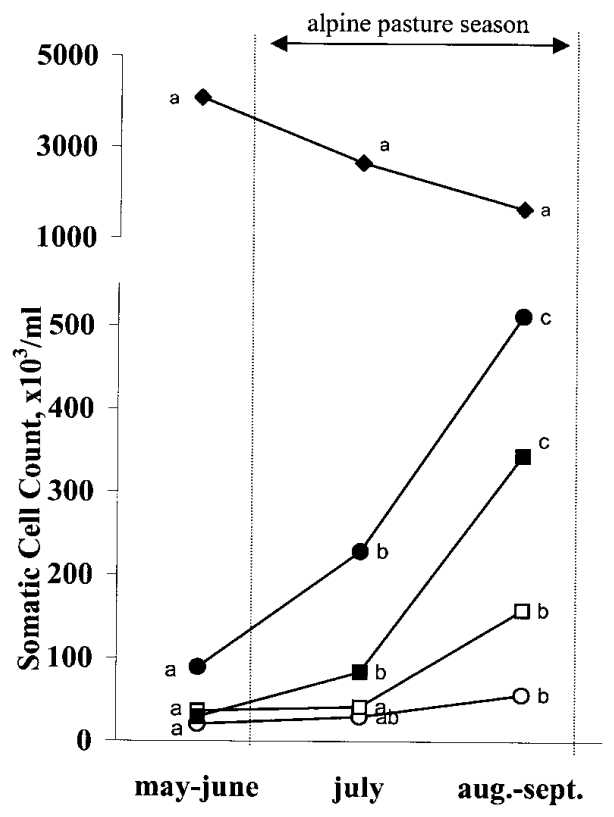

Figure 1. Evolution of milk somatic cell count (geometric means) of quarters not infected in the 3 periods ( $\bigcirc ; 26$ quarters), of quarters infected by a minor pathogen in period 3 ( $\square$; 8 quartiers), in periods 2 and 3 ( $\mathbf{\square} ; 24$ quarters), in the 3 periods (०; 68 quarters) and of quarters infected by a major pathogen in the 3 periods ( $\bullet ; 6$ quarters). Within each evolution, values corresponding to the points with different letters are different at 0.05 level of significance. 
quarters that became infected between the beginning and the end of the study ( 3 months) was low in herds 2 and 3 and clearly greater in herd 1, where none of the infection-limiting measures were taken [23]. As already observed by a number of authors [5, 10, 23], the pathogens qualified as minor were the most frequent. In contrast, the predominance of Streptococcus agalactiae among major pathogens was a surprise because this potentially human pathogen is classically less frequent $[10,21]$.

Due to the difficulty to sample aseptic specimens during milking in alpine pasture, it was not possible to collect specimens for bacteriology and SCC determination during the same milking. But it is unlikely that this may influence the results because the probability of a quarter becoming infected between the 2 samplings (knowing that $10 \%$ of quarters became infected in 100 days) was only $1 \%$ during the first 2 period and $7 \%$ o during the third period.

This study provided a confirmation and ranking of the known effects of infection of udder by pathogens, lactation stage [8] and udder conformation [11, 16] on SCC. Although they were significant, the lactation stage and udder conformation effects were marginal compared to that of quarter infection (approximately 10 times lower). The latter effect was very close to that observed by other authors [3, 22]. Our results also showed that type of minor pathogens had no specific effect on SCC, as already noticed in goats [18]. A herd effect was also evidenced regardless of quarter infection, lactation stage and udder conformation, although no factor was found to explain it. It is possible, however, that the herd effect overshadows a cow effect because when taken into account in the statistical model, the herd effect loses significance.

This study mainly revealed a strong interaction between the infection of udder and the period. This variation in quarter behaviour according to their infectious status cannot be ascribed to the lactation stage, parity, age or breed $[2,8,13,20,24]$ because these characteristics were very close in both groups of cows. The decrease of SCC in quarters infected by a minor pathogen, as observed after returning from alpine pasture, clearly demonstrates the effect of alpine pasture conditions. The level reached remained higher than that before turning to alpine pasture but the difference then was most likely due to the lactation stage (285 days on average at the time of the 4th sampling). Our results were very close to those of Coulon et al. [9] who noted a higher increase in SCC in infected quarters than in non infected quarters after a $10 \mathrm{~km} /$ day forced walk. In this study, when we made an estimate, the

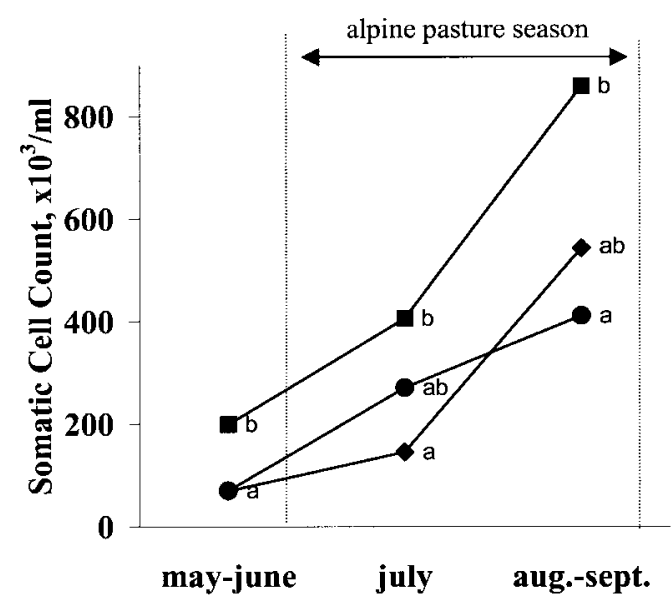

Figure 2. Evolution of milk somatic cell count (geometric means) of quarters infected by a minor pathogen in the 3 periods within the 3 herds $(-$, herd 1 (27 quarters); $\mathbf{\square}$, herd 2 (18 quarters); $\bullet$, herd 3 (21 quarters)). Within each period, values corresponding to the points with different letters are different at 0.05 level of significance. 
Figure 3. Evolution of milk somatic cell count (geometric means) of 30 quarters infected by minor pathogens in the 4 periods. Values corresponding to the points with different letters are different at 0.05 level of significance.

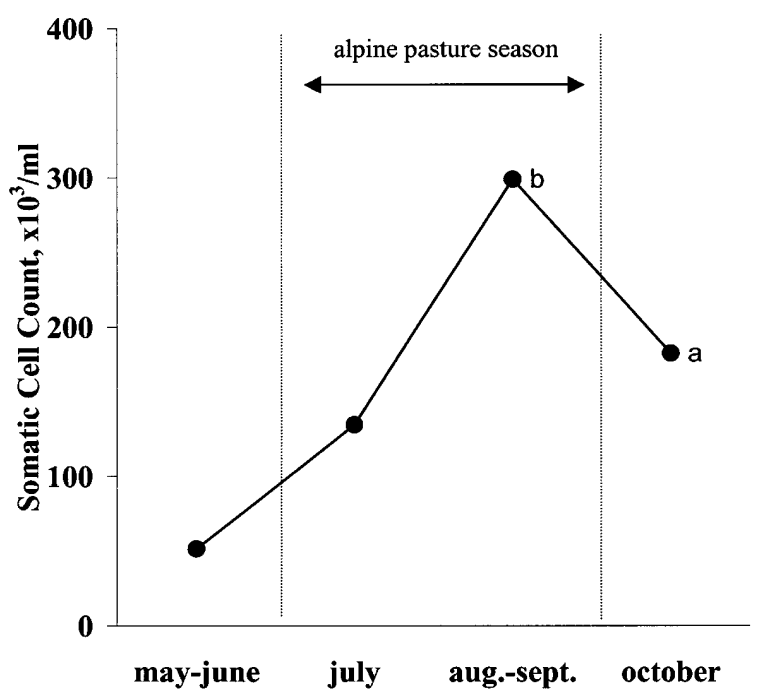

of contamination by major pathogens, herd milks can reach SCC near 500000 cell $/ \mathrm{ml}$ at the end of alpine pasture period, considering that the frequency of non-infected quarters at the end of alpine pasture season was only $25 \%$ in a group of cows whose SCC before turning to alpine pasture was below that classically observed. This study thus showed that it is of particular importance that udders be exempt of any pathogen before turning to alpine pasture. In practice, these increases are also due to infections occurring during alpine pasture season. In areas where alpine pasture is often used, it is all the more important to prevent infection, including those induced by minor pathogens, which under such conditions can contribute to a greater extent in the SCC of milk and consequently penalise breeders.

\section{ACKNOWLEDGEMENTS}

Authors wish to thank the members of GAEC des Glières, du Pragon et du Roignaix, where this study was conducted, the Syndicat de Contrôle Laitier of Savoie as well as J.C. Deillon and K. Delcey who took part in specimen sampling and T. Cochard for performing bacteriological analyses. 


\section{REFERENCES}

[1] Agabriel C., Coulon J.B., Sibra C., Journal C., Hauwuy A., Facteurs de variation de la numération cellulaire du lait en exploitation, Ann. Zootech. 46 (1997) 13-19.

[2] Auldist M.J., Coats S., Rogers G.L., McDowell G.H., Changes in the composition of milk from healthy and mastitic dairy cows during the lactation cycle, Austr. J. Exp. Agric. 35 (1995) 427-436.

[3] Badinand F., Maîtrise du taux cellulaire du lait, Rec. Méd. Vét. 170 (1994) 419-427.

[4] Barbano D.M., Rasmussen R.R., Lynch J.M., Influence of milk cell count and milk age on cheese yield, J. Dairy Sci. 74 (1991) 369-388.

[5] Bartlett P.C., Miller G.Y., Lance S.E., Heider L.E., Clinical mastitis and intramammary infections on Ohio dairy farms, Prev. Vet. Med. 12 (1992) 59-71.

[6] Bartlett P.C., Van Wijk J., Wilson D.J., Green C.D., Miller G.Y., Majewski G.A., Heider L.E., Temporal patterns of lost milk production following clinical mastitis in a large Michigan Holstein herd, J. Dairy Sci. 74 (1991) 1561-1572.

[7] Coulon J.B., Pradel P., Effect of walking on roughage intake and milk yield and composition of Montbéliardes and Tarentaises dairy cows, Ann. Zootech. 46 (1997) 139-146.

[8] Coulon J.B., Dauver F., Garel J.P., Facteurs de variation de la numération cellulaire du lait chez des vaches laitières indemnes de mammites cliniques, Inra Prod. Anim. 9 (1996) 133-139.

[9] Coulon J.B., Pradel P., Cochard T., Poutrel B., Effect of extreme walking conditions for dairy cows on milk yield, chemical composition, and somatic cell count, J. Dairy Sci. 81 (1998) 994-1003.

[10] Faye B., Dorr N., Lescourret F., Barnouin J., Chassagne M., Les infections intra-mammaires chez la vache laitière dans l'enquête écopathologique Bretagne, Inra Prod. Anim. 7 (1994) $55-65$.

[11] Geer D.V.D., Grommers F.J., Van Houten M., Comparison of dairy cows with low or high rate of udder infection, Vet. Quart. 1 (1979) 204-211.

[12] Harmon R.J., Symposium: mastitis and genetic evaluation for somatic cell count, J. Dairy Sci. 77 (1994) 2103-2112.
[13] Kennedy B.W., Sethar M.S., Tong A.K.W., Moxley J.E., Downey B.R., Environmental factors influencing test-day somatic cell counts in Holsteins, J. Dairy Sci. 65 (1982) 275-280.

[14] Lescourret F., Coulon J.B., Modeling the impact of mastitis on milk production by dairy cows, J. Dairy Sci. 77 (1994) 2289-2301.

[15] National Mastitis Council Inc., Microbiological Procedures for the diagnosis of bovine udder infection, Arlington VA, 2201, USA, 1990.

[16] Poutrel B., La sensibilité aux mammites : revue des facteurs liés à la vache, Ann. Rech. Vét. 14 (1983) 89-104.

[17] Poutrel B., Généralités sur les mammites de la vache laitière. Processus infectieux, épidémiologie, diagnostic, méthodes de contrôle, Réc. Méd. Vét. 161 (1985) 497-511.

[18] Poutrel B., Udder infection of goats by coagulase negative staphylococi, Vet. Microbiol. 9 (1984) 131-137.

[19] Statistical Analysis Systems Institute, SAS User's guide: Statistics, SAS Institute, Inc. Cary, north Carolina, USA, 1992.

[20] Schutz M.M., Hansen L.B., Steuernagel G.R., Kuck A.L., Variation of milk, fat, protein, and somatic cells for dairy cattle, J. Dairy Sci. 73 (1990) 484-493.

[21] Seegers H., Menard J.L., Fourichon C., Mammites en élevage bovin laitier : importance actuelle, épidémiologie et plans de prévention, Renc. Rech. Ruminants 4 (1997) 233-242.

[22] Serieys F., Concentration cellulaire du lait individuel de vache : influence de l'état d'infection mammaire, du numéro de lactation, du stade de lactation et de la production laitière, Ann. Rech. Vét. 16 (1985) 255-261.

[23] Serieys F., Les mammites des vaches laitières,

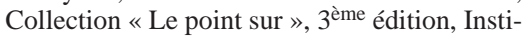
tut de l'élevage, Paris, 1995.

[24] Sheldrake R.F., Hoare R.J.T., Mc Gregor G.D., Lactation stage, parity and infection affecting somatic cells, electrical conductivity and serum albumin in milk, J. Dairy Sci. 66 (1983) 542-547.

[25] Wegner T.N., Schuh J.D., Nelson F.E., Stott G.H., Effect of stress on blood leucocyte and milk somatic cell counts in dairy cows, J. Dairy Sci. 59 (1976) 949-956 